Appeared as: Bidese, Ermenegildo, Andrea Padovan and Claudia Turolla (2019). Adjective orders in Cimbrian DPs. Linguistics 57(2): 373-394 [https://doi.org/10.1515/ling-2019-0004].

\title{
Adjective orders in Cimbrian DPs
}

\author{
Ermenegildo Bidese*, Andrea Padovan ${ }^{+}$and Claudia Turolla*
}

\begin{abstract}
In this work we aim to give a first description of the morphosyntactic behavior of some adjectives in the Cimbrian of Luserna. This Germanic variety allows a subclass of adjectives to appear in post-nominal position. This aspect seems to be relevant, since neither colloquial Standard German nor any other German substandard variety spoken in German-speaking areas display a similar pattern. Along the lines of Cinque $(2010,2014)$, we argue that Cimbrian, with respect to the adnominal adjectival order, has maintained the Germanic pattern of Merge, but permits in some cases NP-Movement above the ("bare" AP reduced) relative clause projection. The fact that adjectives following the head noun are predicative rather than attributive is supported by the fact that post-nominal modifiers never show up with inflection.
\end{abstract}

Keywords: Cimbrian, German-based minority languages, syntax, adjectives, NP-movement

\section{Introduction $^{1}$}

Cimbrian is a German(ic) minority language belonging to the Southern Bavarian dialects and is nowadays spoken only in the small mountain village of Luserna (Lusérn), close to Trento, in the south-eastern Italian Alps (see Bidese 2004); its lexicon shows a number of borrowings from the surrounding Romance dialects, which is a well-known process since the middle ages (see Gamillscheg 1912). Until few decades ago this language was spoken in a much wider area in the Veneto and Trentino regions, in the provinces of Trento, Verona and Bassano del Grappa (see

[Linguistics 57(2), 374]

again Bidese 2004). The varieties of Roana and Giazza, which were slightly different from each other and from the one in Luserna, can be currently considered only as "Erinnerungssprachen" (Bidese 2011: 11), since they are not used anymore in everyday communication, just for recalling traditions and old customs. In fact, they are no longer transmitted to new generations but are taught in language courses instead.

Cimbrian has remained essentially isolated from the other Southern Bavarian dialects since the eleventh century, when this Italian alpine area was first colonized (see Bidese 2004). This fact has allowed both the preservation of morphophonological features, which trace back to older stages of German (see Kranzmayer 1981-1985 [1923]; Tyroller 1994 as well as Alber 2015; Alber and Meneguzzo 2016), and the evolution of - especially syntactical - peculiarities which are unique among the dialects now spoken in Germanspeaking areas, but rather comparable to those found in other Germanic

\footnotetext{
* Ermenegildo Bidese, Dipartimento di Lettere e Filosofia, Università degli Studi di Trento, Via Tommaso Gar 14, 38122, Trento, Italy, E-mail: e.bidese@lett.unitn.it https://orcid.org/00000002-9521-3089; *Claudia Turolla, Dipartimento di Lettere e Filosofia, Università degli Studi di Trento, Via Tommaso Gar 14, 38122, Trento, Italy, E-mail: claudia.turolla@unitn.it; ${ }^{+}$Andrea Padovan, Dipartimento di Lingue e Letterature Straniere, Università degli Studi di Verona, Lungadige di Porta Vittoria 41, 37129, Verona, Italy, E-mail: andrea.padovan@univr.it https://orcid.org/0000-0003-3958-3656
} 
minority languages in Italy such as Walser (see Dal Negro 2004; 2014) and Mòcheno (see Bidese et al. 2012a and especially Cognola 2013).

In recent years generative-inspired research has focused on Cimbrian grammar paying a great deal of attention to (micro)variation and (contactinduced) language change in particular with regard to following topics: (a) Verb-Second. Cimbrian displays neither the German-like Verb Second nor the residual Englishlike pattern; rather, it does invert only the pronominal subject, whereas full DP-subjects usually show up pre-verbally, also together with other constituents (see Bidese and Tomaselli 2007; Bidese 2008; Bidese et al. 2012a); (b) The pronominal system. Cimbrian shows a tripartite structure of personal pronouns, in which a specific form is linked to a specific position: (1) stressed forms are free and behave as full DPs; (2) Preverbal unstressed forms appear alone, i.e. without any other constituent, before the finite verb in main declarative sentences; (3) Postverbal unstressed forms are encliticized onto the finite verb in main declarative sentences and onto the complementizer in subordinate sentences (Poletto and Tomaselli 2002; Bidese 2008; Kolmer 2005, Kolmer 2012; Bidese 2011; Abraham 2011); (c) the subordination system. Cimbrian displays a sophisticated correlation of word order patterns and types of complementizers; some complementizers (prototypically $a z$ 'that') require a word order pattern that is asymmetric with respect to the one found in matrix clauses; other complementizers (prototypically ke 'that', but also ombrómm 'because') a word order pattern that is perfectly symmetric to that of the main sentence trigger (Grewendorf and Poletto 2009, Grewendorf and Poletto 2011; Padovan 2011, Bidese et al. 2012b; Bidese et al. 2013, Bidese et al. 2014; Bidese and Tomaselli 2016).

In this paper we aim for the first time to explore the structure of DP of Lusern Cimbrian focusing on some morphological aspects and on the syntactic

[Linguistics 57(2), 375]

behavior of some adjectives that can appear post-nominally. In fact, Poletto (2013: 90) touches upon this issue depicting Cimbrian adjectives as typical Germanic structures ([A [N]]) totally disregarding the possibility for the adjective to occur post-nominally (see (1a)-(2a) versus (1b)-(2b)):

(1)
a. a naüga
arbat
a new-F.SG.NOM/ACC job
'a new job'
(Poletto 2013: 90) ${ }^{2}$

b. ??an arbat naüga

a job new-F.SG.NOM/ACC

(2) a. a gelz haus

a yellow-N.SG.NOM/ACC house

'a yellow house'

b. ??a haus gelz

a house yellow-F.SG.NOM/ACC

\footnotetext{
${ }^{1}$ We inserted the glosses and adapted the Examples to the official orthography adopted with Panieri et al. (2006).
} 
However, it must be observed the these examples, reproduced by Poletto, are not relevant for the discussion here, since the adjectives naüge 'new' in (1) and gel 'yellow' in (2) show the strong declension (which is obligatory only with the indefinite article or no article at all): see the suffix - $a$ for feminine singular, nominative or accusative in (1), and in (2) the suffix $-z$ for neuter singular, nominative or accusative. Inflected adjectives are, indeed, totally excluded in the post-nominal position, not only in Cimbrian but also in German. Instead, the significant pattern which we discuss in this article crucially deals with uninflected post-nominal adjectives. In this case Cimbrian allows for some adjectival classes to be realized also after the noun. This position is also available in Standard German but to a lesser extent and in any other non-standard variety in use in the German-speaking areas, which makes the Cimbrian pattern unique among the German varieties and interesting from both a theoretical and a comparative perspective. ${ }^{3}$

[Linguistics 57(2), 376]

As for the structure of the contribution, we present the inflectional system of the adjectives in contemporary Lusern Cimbrian - which has undergone a process of morphological leveling - showing that the actual paradigm is better explained in terms of loss of inflectional morphology rather than in terms of preservation of an archaic pattern (see Section 2). In Section 3 we discuss the possibility that adjectives occur post-nominally with the restrictions connected to this novel scenario: we will show that not all orders are attested. Section 4 is devoted to the analysis that we put forward along the lines of Cinque $(2010,2014)$ : crucially, we argue that Cimbrian maintains the Germanic pattern of adjective ordering, allowing nevertheless for a wider range of structural variation. In Section 5 we briefly compare the situation of Cimbrian adjectives with some erratic data found in Mòcheno, a neighboring Germanic language and provide a general conclusion.

\section{Adjectival morphology in Cimbrian}

Both traditional descriptions and recent grammars have distinguished between - the typically Germanic - strong and weak declensions in the Cimbrian adjectival morphology: we begin with traditional descriptions of which we give a quick historical overview.

Schmeller (1838: 678-680) briefly referred ${ }^{4}$ to a first and a second declension of adjectives although he noticed that the two declensions are not kept separate in all cases: "This second type has been clearly kept different from the first declension; however, examples of the confusion of the two classes are also found". ${ }^{5}$

\footnotetext{
${ }^{3}$ For a general overview of Germanic adjectives see also Roehrs (2014). Moreover, Kotowski and Härtl (this volume) offer an overview about the restrictions prenominal adjective are subjected to in German(ic).

${ }^{4}$ Schmeller is mainly concerned with the Cimbrian varieties of the Seven and the Thirteen Municipalities, but the internal differences can be abstracted away from, since there is consistency among all the Cimbrian varieties.

${ }^{5}$ Our translation: "Das Gefühl für den Unterschied dieser zweiten von der ersten Declinationsweise der Adjektive hat sich sehr lebhaft erhalten. Doch fehlt es nicht an Beispielen der Verwechslung beider".
} 
More than a century later, Bruno Schweizer pointed out in his grammar (2008 [1951/1953]: 389) that in the Cimbrian dialects of Giazza, Roana and Lusérn the following typologies exist:

(1) The strong declension with the endings pronominal inflection, which is basically used with or without the definite article, (2) the weak declension with the endings of the Nstems and (3) an uninflected form which sometimes occurs instead of both the weak and the strong declensions. ${ }^{6}$

[Linguistics 57(2), 377]

With regard to these last forms, the author adds that "the usage of these uninflected forms is still poorly understood". Thus, in Schweizer's time, uninflected forms begin to show up in contexts where inflection is expected.

Concerning contemporary descriptions of Luserna Cimbrian, the grammar by Tyroller (2003) also distinguishes between a weak declension, preceded by the definite article, and a strong declension, which follows the indefinite article. For the former, he emphasizes that the nominative singular turns up with zero morphology, as in (3), (4) and (5) (see Tyroller 2003: 141148): ${ }^{8}$

(3) dar groaz månn

the tall-ø man

'the tall man'

(4) di voll boza

the full-ø bottle

'the full bottle'

(5) daz grümma gras

the green- $\varnothing$ grass

'the green grass'

Uninflected forms also appear in accusative singular feminine and neuter, while the morpheme -an and its allomorphs show up in dative for all genders, as in (6) and (7), in accusative masculine, as in (8), and in plural for all cases and genders:

(6) in groazan månn

the-M.SG.DAT big-M.SG.DAT man

'to the big man'

(7) dar müadn khua

the-F.SG.DAT tired-F.SG.DAT cow

'to the tired cow'

[Linguistics 57(2), 378]

\footnotetext{
${ }^{6}$ Our translation: “[ ... ] (1) die starke Flexion mit den Endungen der pronominalen Flexion, die im Wesentlichen ohne oder mit unbestimmtem Artikel gebraucht wird, (2) die schwache Flexion mit Endungen der N-Stämme, (3) eine unflektierte Form, die gelegentlich an Stelle der schwachen Flexion aber auch der starken eintreten kann."

${ }^{7}$ Our translation: „man durchblickt noch nicht ganz deutlich die Verwendung der endungslosen (,unflektierten") Form“".

${ }^{8}$ The orthographic rules followed here are the ones adopted in Panieri et al. (2006).
} 
(8) di grüanen grésar

the-N.PL.NOM green-N.PL.NOM herbs

'the green herbs'

On the other hand, the strong declension displays an inflectional suffix for each case and gender, both in singular and in plural: the morpheme -ar for the nominative masculine singular, as in (9), - $a$ for the nominative and accusative feminine singular, as in (10), $-(e) z$ and its allomorphs for the nominative and accusative neuter, as in (11), $-e$ for the nominative and accusative plural of the three genders, as in (12), -an and its allomorphs in the other cases, as in (13):

(9) a schüanar tage

a beautiful-M.SG.NOM day

'a beautiful day'

(10) a guata muatar

a good-F.SG.NOM mother

'a good mother'

(11) a tiavez tal

a deep-N.SG.NOM valley

'a deep valley'

(12) bravate khindar

well-behaved-N.PL children

'well-behaved children'

(13) an hoatarn hümbl

a-M.SG.ACC bright-M.SG.ACC sky

'a bright sky'

The grammar of Panieri et al. (2006: 124-142) also identifies a weak declension, which shows up if the adjective follows either the definite article or the demonstrative pronouns in attributive function, and a strong one, which is found if the adjective follows the indefinite article, the possessive pronouns in their adjectival function, and in general the indefinite pronoun in attributive function, or if no determiners precede the adjective.

For the weak declension the authors emphasize that the singular forms exhibit strong morphological differences due to the syllabic structure or the phonetic characteristics of the adjective (see Panieri et al. 2006: 124-142); for

[Linguistics 57(2), 379]

instance, monosyllabic adjectives like groaz 'tall', voll 'full', barm 'warm' or guat 'good' show "a really simple inflectional pattern [...], in which only the 
dative feminine singular and all plural forms carry the suffix $-n$ while the other forms are not inflected"' (see Table 1):

Table 1: Weak declension of monosyllabic adjective in Cimbrian according to Panieri et al. (2006: 127).

\begin{tabular}{|c|c|c|c|c|}
\hline CASE & MASC. SING. & FEM. SING. & NEUT. SING. & PLURAL \\
\hline NOM. & $\begin{array}{c}\text { dar alt månn } \\
\text { 'the old man' }\end{array}$ & $\begin{array}{c}\text { da guat diarn } \\
\text { 'the good girl' }\end{array}$ & $\begin{array}{c}\text { daz groaz khinn } \\
\text { 'the tall boy' }\end{array}$ & $\begin{array}{c}\text { di guat-n månnen } \\
\text { 'the good men' }\end{array}$ \\
\hline DAT. & $\begin{array}{c}\text { in alt månn } \\
\text { (to) the old man' }\end{array}$ & $\begin{array}{c}\text { dar guat-n diarn } \\
\text { '(to) the good girl' }\end{array}$ & $\begin{array}{c}\text { in groaz khinn } \\
\text { '(to) the tall boy' }\end{array}$ & $\begin{array}{c}\text { in guat-n mainnen } \\
\text { 'the good men' }\end{array}$ \\
\hline ACC. & $\begin{array}{c}\text { in alt månn } \\
\text { 'the old man' }\end{array}$ & $\begin{array}{c}\text { da guat diarn } \\
\text { 'the good girl' }\end{array}$ & $\begin{array}{c}\text { daz groaz khinn } \\
\text { 'the tall boy' }\end{array}$ & $\begin{array}{c}\text { di guat-n månnen } \\
\text { 'the good men' }\end{array}$ \\
\hline
\end{tabular}

Belonging to this category are also: (a) disyllabic adjectives ending up in liquid consonants ( $r, 1)$ like saubar 'clean' or tunkhl 'dark'; (b) disyllabic adjectives that denote a material, such as boatza 'wheaten', ${ }^{10}$ hültzra 'wooden' or aisra 'of iron' and (c) disyllabic adjectives ending up in -mma like khlumma 'small', schümma 'beautiful' or grümma 'green' which derive from the older monosyllabic forms khluan, schüan and grüan. ${ }^{11}$

The fact that the weak declension has several uninflected forms can be explained adopting two different approaches, both of them representing an interesting point of discussion for the morphological diachronic development of a minority language which has evolved without further contact with its formerly cognate varieties and has only recently known a standardization process. As a matter of fact, the lack of inflectional morphology can be seen as an sign of a more archaic stage, since in the Middle High German (see Paul 2007: 200-201) there was a weak declension corresponding to the third class of the nouns and a strong declension which resembled the one of pronouns but uninflected adjectives in pre-nominal position were also possible: "an

[Linguistics 57(2), 380]

uninflected, nominally-strong form exists, occurring when the attributive adjective precedes the noun it modifies, namely in the nominative singular of all genders and in the accusative neuter singular". ${ }^{12}$

Moreover, if one considers the first Cimbrian Catechism of 1602 (see Meid 1985), which documents a stage of language earlier than the one described by Schweizer, Tyroller, and Panieri, one finds that adjectives of the weak declension - i.e. the ones preceded by a definite article - display inflection in nominative and accusative of all genders, as in (14) and (15):

$$
\begin{array}{lll}
d a & \text { rekte } & \text { hant } \\
\text { the-F.SG.NOM } & \text { right-F.SG.NOM } & \text { hand }
\end{array}
$$

\footnotetext{
${ }^{9}$ Our translation: "ein sehr einfaches Flexionsmuster [ ... ], bei dem lediglich der Dativ Singular der Feminina und alle Pluralformen die Endung $-n$ tragen, während die anderen Formen nicht flektiert werden".

${ }^{10}$ As Panieri et al. (2006: 130, fn. 41) notices, these forms derive from the original derivational suffix -in (see Middle High German weitzin 'wheaten').

${ }^{11}$ Even for all these types Tyroller (2003: 144-145) reports the suffix $-n$ also for M.SG.DAT. and ACC (see above Note 8).

12 "die endungslose, nominal-starke Form schließlich kann [ ... ] stehen, wenn das attributive Adj. seinem Bezugswort vorangeht, und zwar in NOM.SG. aller Geschlechter und im AKK.SG. NEUT.: der bluotec sweiz; ein gout man".
} 
'the right hand'

(15) der ebeghe toat
the-M.SG.NOM eternal-M.SG.NOM death
'the eternal death'

Since the first Catechism was written in the Cimbrian of the VII municipalities and not in the variety of Luserna, one might assume that the two varieties differ in terms of inflectional suffixes and that the Luserna dialect has always had uninflected forms with regard to the weak declension. However, referring to the Cimbrian tales collected by Bacher (1976 [1905]: 171), Schweizer (2008 [1951/ 1953]) mentions the possibility of some morphological remnants of weak declension also for this variety attesting, for instance, both uninflected (see 16) and inflected forms (see 17):

(16) da rôat earde

the red- $\varnothing \quad$ earth

'the red earth'

(Schweizer 2008 [1951/1953]: 390)

(17) de kxalte tzait

'the cold-F.SG.NOM period'

Summarizing the data presented in this section, we can say that the Cimbrian system of adjectives displays a clear distinction between a weak and a strong declension. While the former one does not show any inflectional suffix except

[Linguistics 57(2), 381]

for an $-n$ in the form of the dative feminine singular (see, however, also fn. 8 and 10) and in the plural forms, the later one preserves the endings in all genders and cases as well as both in singular and in plural. As far as the lack of inflection in the weak declension is concerned, we have provided evidence that it can be interpreted as the result of an erosion process that has led to the loss of the suffixes with the above-mentioned exception.

\section{Novel patterns in adjective orderings}

In the preceding Section we have proposed a possible pattern of evolution of the two inflectional classes of adjectives (strong vs. weak) reconstructing a gradual erosion of forms with respect to the weak declension. Independently of these leveling phenomena the position of the adjective was consistently pre-nominal. In this Section we deal with post-nominal occurrences that correlate structurally - i.e. independently of any erosion process - with an uninflected form. ${ }^{13}$ This distribution had already been observed in the past and does not seem to be connected with code-switching, as proposed for Mòcheno (see Alber forthcoming and Section 5, above).

\footnotetext{
${ }^{13}$ As already said in the introductive Section, we do not deal with uninflected adjectives occurring post-nominally since these forms are totally excluded.
} 
As for the diachronic evolution of the word order pattern within the adjectival system there is no consistent set of data: it is hard both to trace back its emergence and to ascertain whether this phenomenon is connected to previous stages of the language or is to ascribe to recent evolution. The oldest data available stem from 1602 when Cardinal Bellarmine's Catechism, "Dottrina Cristiana Breve (Short Christian Doctrine)", was translated into Cimbrian, (see Meid 1985).

In this work, post-nominal adjectives are relatively rare and in general occur with direct borrowings (see Padovan and Turolla 2016) as can be observed in the following examples, where the Italian lexeme is directly inserted into the Cimbrian DP without any adaptation.

(18) mitt unzerme contenten spirituale

with our-M.SG.DAT joy-M.SG.DAT spiritual- $\varnothing$

(Italian: "con nostro contento spirituale")

'with our spiritual rejoicing'

[Linguistics 57(2), 382]

(19) Vatter naturale

father-M.SG.NOM natural- $\varnothing$

'natural father'

Notice that the canonical position for native adjectives is the pre-nominal one, see examples (14-15) repeated here as (20-21).

(20) da rekte hant

the-F.SG.NOM right-F.SG.NOM hand

'the right hand'

(21) der ebeghe toat

the-M.SG.NOM eternal-M.SG.NOM death

'the eternal death'

As diachronic investigations have not provided us with consistent results, we have assumed that synchronic data collection might cast light on the systematic distribution of adjectives. Let's now go back to the methodology. As regards the fieldwork, it can be divided in two different stages: in the first pilot testing we administered a translation task (from Italian into Cimbrian) to five informants: in many cases the word order proposed was nounadjectives - which often is the unmarked option in Italian. The initial data were often inconsistent as it was not possible to determine which adjectival classes allow for the post-nominal position. This is why we carried out new fieldwork, refining the methods of investigation: first of all, we administered the tasks to a larger group of informants (15 Cimbrian speakers aged between 18 and 68 years); then we added grammaticality judgment tasks containing DPs with both pre- and post-nominal orders of the adjectives. We also increased the number of sentences dividing the adjectives systematically into semantic classes. 
The informants were asked to rank the sentences in Cimbrian containing DPs modified by one or two adjectives according to the following judgment scale:

(1) ungrammatical sentence

(2) odd but still grammatical ${ }^{14}$

(3) grammatical sentence.

[Linguistics 57(2), 383]

\subsection{One modifier}

If just one single adjective modifies the noun the frequency of the [A N] order - i.e. the one expected in a Germanic language - is the highest one with both intersective (I) (see (22)-(24)) and subsective adjectives (S) (see (25)(27)).

This does not come as a surprise if one relies on what is claimed in recent traditional grammars of this heritage language (see the abovementioned descriptions of the grammar of Cimbrian: Tyroller 2003; Panieri et al. 2006): Cimbrian adjectives are taken to be usual Germanic adjectives strictly occurring in pre-nominal position; our data confirms this basic tendency (we deal with deviance later on).

Intersective adjectives: color

a. Dar roat libar iz attn skafàl the red-M.SG.NOM ${ }^{15}$ book is on-the shelf 'The red book is on the shelf'

b. *Dar libar roat iz attn skafâl the book red- $\varnothing$ is on-the shelf

(23) a. Dar Håns hatt inngemekkèt in scharnagl pinn the Håns has hammered the nail with-the-M.SG.DAT sbartz håmmar

black-M.SG.DAT hammer 'Hans hammered the nail with the black hammer'

b. "Dar Håns hatt inngemekkèt in scharnagl pinn the Håns has hammered the nail with-the-M.SG.DAT

håmmar sbartz

hammer black- $\varnothing$

(24)
a. Pitt moin
geln
auto von 1990 geade $k a$
with my-M.SG.DAT yellow-M.SG.DAT car of 1990 go-I to
Tria alle di mòrgas

\footnotetext{
${ }^{14}$ Passive competence of the construction was also ranked 2. As is often the case, minority languages display what is dubbed "low normativity effect" (Dorian 2010 based on Lindgren 1999), i.e. different speakers tend to accept constructions they would not produce themselves but other speakers of the community utter: such structures are not judged ungrammatical but are perceived as odd basically as they belong to a specific register (specifically the often frownedupon juvenile jargon).

${ }^{15}$ As we have already shown in Section 2, the pre-nominal form preserves its $\varphi$-features although it does not manifest them overtly, whereas the post-nominal occurrence is taken to be a bare form devoid of any $\varphi$-features.
} 
Trento all the mornings

'With my 1990 yellow car I go to Trento every morning'

[Linguistics 57(2), 384]

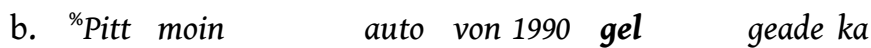

with my-M.SG.DAT car of 1990 yellow- $\varnothing$ go-I to

Tria alle di mòrgas

Trento all the mornings

Intersective adjectives: material

(25) a. Dazkhelbra vlaisch iz daz peste

the of.calf-N.SG.NOM meat is the best

'(The) veal is the best'

b. ${ }^{*}$ ' $Z$ vlaisch khelbra iz daz peste

the meat of.calf- $\varnothing$ is the best

(26) a. Di Maria hatt gevuntet a goltnaz gevringat

the Maria has found a golden-N.SG.ACC ring

'Maria found a golden ring'

b. 'Di Maria hatt gevuntet a gevringat goltna

the Maria has found a ring golden- $\varnothing$

(27) a. Pan bintar geabar hèrta auz pitt bollan

in-the winter go-we always out with woolen-PL.DAT

hångas un halstuach

mittens and scarf

'In winter we always go out with woolen mittens and scarf on'

b. *Pan bintar geabar hèrta auz pitt hångas un halstuach bolla in-the winter go-we always out with mittens and scarf- $\varnothing$ wollen

Subsective: Value

(28) a. A guatar vatar straitet nèt pitt soin khindar a good-M.SG.NOM father argues not with his children 'A good father never argues with his children'

b. *A vatar guat straitet nèt pitt soin khindar

a father good- $\varnothing$ argues not with his children

(29) a. I halte nemear auz in zèngrat gesmàkh vo kafe I stand no-longer out the bitter-M.SG.ACC taste of coffee 'I can't stand the bitter taste of coffee any longer'

[Linguistics 57(2), 385]

b. \%I halte nemear auz in gesmàkh zèngrat vo kafê

I stand no-longer out the taste bitter- $\varnothing$ of coffee 
(30) a. I hån gelek di slüzzldar in an khlumman kasetì I have put the keys in a-M.SG.DAT small-M.SG.DAT drawer 'I put the keys in a small drawer'

b. *Ihån gelek di slüzzldar in an kasetì khlumma I have put the keys in a-M.SG.DAT drawer small- $\varnothing$

Subsective: dimension

(31) a. Vonan hoachan pèrge hånne nidargeschauget in tal from-the high-PL.DAT mountains have-I overlooked the valley 'From the top of the high mountains I overlooked the valley'

b. *Vonan pèrge hoach hånne nidargeschauget in tal from-the mountains high- $\varnothing$ have-I overlooked the valley

To sum up, along with normal Germanic adjectives there is a small class of intersective (see 23 and 24) and subsective (29) adjectives that are also allowed post-nominally. Why is it the case? Is Cimbrian in a somehow special position between Italian and German?

First of all, Italian allows for both categories, S and I, to appear in a postnominal position, whereas German in general tolerates no adjectives occurring post-nominally. ${ }^{16}$

\subsection{Two modifiers}

Another interesting aspect in our survey turns up when it comes to two modifiers. On the one hand both orders $\mathrm{S}>\mathrm{I}$ and $\mathrm{I}>\mathrm{S}$ are possible when the adjectives

[Linguistics 57(2), 386]

are pre-nominal; on the other hand, either adjective can appear in a postnominal position: however, data are not consistent with respect to the class of adjectives that can show up in the post-nominal position (32-34):
a. Dar roat
boróaslte
konzòtt iz dar
the red-M.SG.NOM flowered-M.SG.NOM dress is the schümmanarste
most-beautiful
'The red-flowered dress is the prettiest one'
b. Dar boróaslt roat konzòtt iz dar schümmanarste
c. ${ }^{\%}$ Dar roat konzòtt boróaslt iz dar schümmanarste
d. *Dar boróaslte konzòtt roat iz dar schümmanarste

\footnotetext{
${ }^{16}$ Both in German dialects and in the standard language post-nominal adjectives are either excluded or extremely restricted. However, Dürscheid (2002) and Trost (2006) describe several examples in which post-nominal adjectives in Standard German are productive like in Forelle blau (blue trout), Fußball brutal (brutal soccer), Schrauber verzinkt (zinc coated screw). Nevertheless, these NPs only occur isolated and in marked registers such as newspaper titles, advertisement and commercials (see Dürscheid 2002: Wohnwagen gross, sofort einsatzbereit 'big caravan, ready for use'), menus and in rhyme (see Trost 2006: Das Mägdlein gut, bringt dir den Muth 'The good maid gives you the nerve', Achim v. Arnim u. Clemens Brentano: Schwere Wacht. Jungfrau und Wächter).
} 
(33) a. ${ }^{\%} Z$ khinn spilt pitnan valsan sklopp hülzra the kid plays with-the-M.SG.DAT false-M.SG.DAT rifle wooden- $\varnothing$ 'The kid is playing with a wooden toy rifle'
b. *'Z khinn spilt pitnan
hülzran
sklop vals the kid plays with-the-M.SG.DAT wooden-M.SG.DAT rifle false- $\varnothing$ the Mario has put the silver-F.SG.ACc frame new- $\varnothing$ on-the tisch

table

'Mario put the new silver frame on the table'

b. *Dar Mario hatt gelekkdi naüge kornis silbran attn the Mario has put the new-F.SG.ACC frame silver-ø on-the tisch

table

In general, the free order of intersective adjective pairs does not come as a surprise (see Truswell 2009, among others) as it is possible, to different extents, in several languages. However, subsective adjectives are known to precede intersective adjectives in Germanic and to follow them in Romance languages (cf. new red dress/??red new dress and vestito rosso nuovo/??vestito nuovo rosso) (new woolen short/*woolen new short) but this does not seem to be the case in Cimbrian where the order of preverbal adjectives turns out to be apparently free $(\mathrm{S}>\mathrm{I} / \mathrm{I}>\mathrm{S})$ (vals hülzra sklopp/hülzra vals sklopp).

[Linguistics 57(2), 387]

\subsection{Specificity-inducing adjectives}

As for specificity-inducing adjectives such as old, big, poor, etc. our data provides evidence for a possible non-specific interpretation of post-nominal adjectives in indefinite DPs reminiscent of Cinque's (2014) view on Romance:

(35) a. An altar pürgarmaistar vo Lusérn hatt gemacht an old-M.SG.NOM mayor of Luserna has done vil vordi djungen a-lot for the young 'An old mayor/A former mayor of Luserna did a lot for the young'

b. ${ }^{\%} A n$ pürgarmaistar alt mage nèt redjarn an mayor old-ø can not administer 'An old mayor cannot administer the town (properly)'

(36) a. Sa håm vortgeschickt in arm maistro they have fired the poor-M.SG.ACC teacher 'They fired the poor teacher/the pitiable teacher'

b. "Darsell maestro arm håt nèt gelt genumma that teacher poor-ø has not money enough 'That poor teacher hasn't got money enough' 
(37) a. Dar institut hatt gemacht a groazaz börtarpuach the institute has done a great-N.SG.ACC dictionary 'The institute published a good quality dictionary/an unwieldy dictionary'

b. *'Z börtarpuach groaz tragez nèt nå umbromm'zsbert vil the dictionary great- $\varnothing$ carry-I-it not along since it weighs a-lot 'I'm not bringing the unwieldy dictionary as it weighs too much'

Looking at the data, the following questions arise: first of all, how to make sense of the order $\left[\mathrm{A}_{1} \mathrm{~N}_{2}\right]$ like in da silbran kornis naüge 'the silver frame new' (see 29b), should we hypothesize an influence from the neighboring Romance varieties (see Alber et al. 2012)? If it is indeed the case that Romance word order in APs affects Cimbrian, can the contact situation be described in terms of microvariation (along the lines of Guardiano 2014, according to which parameters in the bilingual mind are more likely to be reset)?

As we will show in the next paragraphs, our stance is that the role of language contact may amount to widening the range of possibilities available (see Panagiotidis 2008).

[Linguistics 57(2), 388]

\section{Analysis}

At the beginning of the paper we pointed out that the behavior of adjectives follows a quite clear-cut directions: the typology of the orderings [Adjective $\mathrm{N}$ ] or [N Adjective] is something quite inescapable. However - as we have seen - there seems to be a new pattern emerging in an otherwise clearly regular Germanic language. How is this new strand of Cimbrian data to be dealt with? Should we attribute this innovation either to the resetting of microparameters in the sense of Guardiano (2014) or to the introduction of uninterpretable features in functional categories as hinted at by Panagiotidis (2008)?

Along the lines of Cinque (2010, 2014), Giusti (2002) and Laenzlinger (2005), we assume that Cimbrian adjectives maintain the Germanic pattern of Merge, according to which the noun plus the direct modification adjective is merged with a reduced relative clause:

(38)

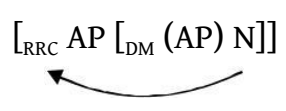

(cf. Cinque 2014: 19)

In Cimbrian this is instantiated in, e.g. $\left[_{\mathrm{RRC}}\right.$ a naüge $\left[_{\mathrm{DM}}\right.$ silbran [cornis]]] ('a new silver frame'). For the Romance languages, Cinque argues that the noun can optionally raise across one or more direct modification adjectives: this optional movement must be followed by obligatory raising of the noun plus direct modification adjective(s).

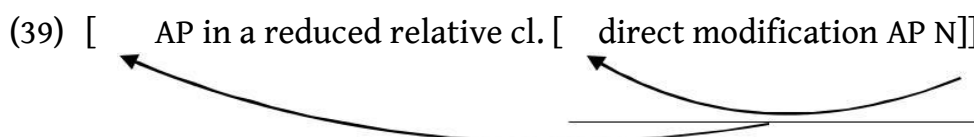


In Italian this movement is exemplified by phrases such as:

(40) a. [RRC un corrotto [DM giovane [avvocato]]]

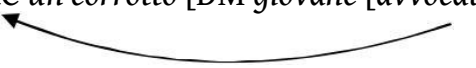

b. [RRC un corrotto [DM avvocato giovane avvocato]]]

c. [un avvocato giovane [RRC corrotto [DM 'a corrupt young lawyer'

What we argue for Cimbrian regards on the one hand the inapplicability of the optional raising of the noun across the direct modification adjectives, as can be observed in (41):

[Linguistics 57(2), 389]

(41) *Da naüge kornis silbran

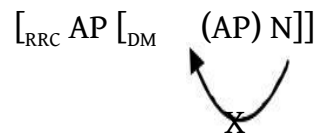

On the other hand, the cluster formed by direct modification adjectives plus noun can, but need not, move as NP in front of the reduced relative cl. adjectives (see 42a-b):

(42) a. da naüge silbran kornis

b. $\quad{ }^{2}$ da silbran kornis naüge attn tisch

Notice that the pattern in (42b) is attested neither in Italian (Romance) nor in German; however, a very interesting parallel with some English RRC adjective classes can be drawn, even though the classes are not entirely overlapping (see Cinque 2014):

(43) the $\left[_{\text {RCC }}\right.$ available $\left[_{D M}\right.$ former students $] \rightarrow$ the former students available former students

Structures like the ones under (42b) showcase a definitely new feature in the Cimbrian DP: should one take them by and large for contact-induced phenomena? It would be prima facie hard to do so as these constructions are not attested in the model language(s) (Italian and, to a certain extent, German). However - as is the case of the borrowing of functional words in Cimbrian such as the complementizer ke (see Grewendorf and Poletto 2009; Padovan 2011 and Bidese et al. 2012b) - we argue that language contact is not instantiated by the mere transfer of structures (which is never the case) but, quite differently, contact manifests itself in favoring the emergence of new alternatives, whose coming into being is allowed by the system and only upheld by the contact situation.

Having this in mind, we can finally go back to the cases under (23b)(24b) and (29b) and (35b), (36b), where the post-nominal occurrence of both intersective/subsective and specificity-inducing adjectives might be considered to mirror the Romance pattern [N AP]: on the contrary, we take that resemblance to be only superficial as it merely represents a further possibil- 
ity acquired into the Cimbrian DP. First of all, they are always pragmatically marked structures and hence their distribution is not reminiscent of Italian; secondly, post-nominal adjectives are always uninflected and this definitely points to their reduced relative clause origin.

[Linguistics 57(2), 390]

\section{Concluding remarks}

Patterns similar to the ones attested in Cimbrian can be found in Mòcheno, a neighboring Germanic variety also spoken in the Province of Trentino. Mòcheno noun phrases closely resemble those of Standard German(ic), as determiners and adjectives typically precede the noun. Rowley (2001: 117) mentions erratic examples, of very recent attestation, where an adjective can actually follow the noun provided that it occurs in its uninflected form. The Examples originally appeared in Mattiola (1985: 89) and Zampedri (1995: 87-88) are the following:

(44) pet en trit gabis with a step determined-ø

'with a determined step'

(45) van binter vergongen

from winter passed- $\varnothing$

'of the past winter'

(46) pet de masciindl elektrisc

with the machine electric- $\varnothing$

'with the electric machine'

It is not easy to determine whether these structures have arisen under Romance influence since they look more like products of code-switching rather than true (structural) borrowings, given their rareness (see Alber et al. 2012 for similar structures in the Cimbrian of Giazza, where they seem to be more widespread). Moreover, this phrases have the feel of something idiomatic and basically fixed in its form. In fact, as for (45) the form vergongen ('passed') is a past participle and its post-nominal occurrence does not come as a surprise. Elektrisc was - at the time when Rowley published his monograph - perceived as a neologism. ${ }^{17}$

Concluding, in this paper we have shown that contact may have played a role in the reordering possibilities of the Cimbrian DP which allows for more orders than German. As is the case with other grammatical features (complementizers, embedded V2, etc.), contact does not manifest itself in structure borrowing, but in maintaining change that is already hard-wired in the

[Linguistics 57(2), 391]

\footnotetext{
${ }^{17}$ Curiously, both 'past' and 'electric' can occur post-nominally in English in certain contexts: recall 'The Ghost of Christmas Past' in Dickens's A Christmas Carol and the famous line by Walt Whitman 'I sing the body electric', where the adjective electric - which was not commonly used at the time - shows up in a post-nominal, possibly emphatic, position.
} 
language. In particular, the post-nominal position of adjectives is not excluded in Germanic but is very restricted: Cimbrian has simply moved to a status in which the classes of adjectives that occur post-nominally are gradually increasing, at least in the grammars of a group of speakers.

Acknowledgements: This contribution was written by the authors in complete collaboration. For the formal definition of scholarly responsibility, as required by the Italian academic system, we declare that Ermenegildo Bidese draws up the Sections 1. and 2., Andrea Padovan the Sections 4 and 5, and Claudia Turolla the Section 3. The contents of this article were presented at the 38th Annual Meeting of the Gesellschaft für Sprachwissenschaft (DGfS), AG 13: Adjective Order: Theory and Experiment (Konstanz, 24-26 February, 2016). This work is part of the project AThEME (Advancing the European Multilingual Experience) funded by the European Union's Seventh Framework Programme for research, technological development and demonstration under grant agreement no. 613465. We thank the anonymous reviewers for their comments and useful feedback, as well as Eva Wittenberg and Andreas Trotzke for their editorial effort. Any inaccuracies and inconsistencies remain our own.

\section{References}

Abraham, Werner. 2011. Spoken syntax in Cimbrian of the linguistic islands in Northern Italy And what they (do not) betray about language universals and change under areal contact with Italo-Romance. In Michael T. Putnam (ed.), Studies on German language Islands (Studies in Language Companion Series 123), 233-278. Amsterdam \& Philadelphia: John Benjamins.

Alber, Birgit. 2015. Die deutschen Sprachinseln der Zimbern und Fersentaler in Norditalien. Konservativität, Innovation und Kontakt im Lautsystem. In Rainer Schlösser (ed.), Sprachen im Abseits. Regional- und Minderheitensprachen in Europa, 19-45. Munich: AVM.

Alber, Birgit. forthcoming. Mòcheno. In Hans Boas, Ana Deumert, Mark L. Louden \& Péter Maitz (eds.), Varieties of German worldwide. Oxford: Oxford University Press.

Alber, Birgit \& Marta Meneguzzo. 2016. Germanic and Romance onset clusters - How to account for microvariation. In Ermenegildo Bidese, Federica Cognola \& Manuela Caterina Moroni (eds.), Theoretical Approaches to Linguistic Variation (Linguistik Aktuell/Linguistics Today 234), 25-51. Amsterdam \& Philadelphia: John Benjamins.

Alber, Birgit, Stefan Rabanus \& Alessandra Tomaselli. 2012. Contatto linguistico nell'area alpina centromeridionale. In Laura Maria Colombo, Rosanna Gorris \& Paola Perazzolo (eds.), La sensibilità della ragione. Studi in omaggio a Franco Piva, 1-19. Verona: Edizioni Fiorini.

Bacher, Josef. 1976 [1905]. Die deutsche Sprachinsel Lusern. 2nd edn. Vienna: Verband der wissenschaftlichen Gesellschaften Österreichs.

Bidese, Ermenegildo. 2004. Die Zimbern und ihre Sprache: Geographische, historische und sprachwissenschaftlich relevante Aspekte. In Thomas Stolz (ed.), „Alte“ Sprachen.

[Linguistics 57(2), 392]

Beiträge zum Bremer Kolloquium über „Alte Sprachen und Sprachstufen“ (Bremen, Sommersemester 2003) (Diversitas Linguarum 8), 3-42. Bochum: Brockmeyer.

Bidese, Ermenegildo. 2008. Die diachronische Syntax des Zimbrischen. Tübingen: Gunter Narr.

Bidese, Ermenegildo. 2011. Revisiting the Wackernagelposition: The evolution of the Cimbrian pronominal system. In Michael T. Putnam (ed.), Studies on German-language Islands (Studies in Language Companion Series 123), 347-367. Amsterdam \& Philadelphia: John Benjamins.

Bidese, Ermenegildo, Federica Cognola \& Andrea Padovan. 2012a. Zu einer neuen Verb-ZweitTypologie in den germanischen Sprachen: Der Fall des Zimbrischen und des Fersentalerischen. In Peter Anreiter, Ivo Hajnal \& Manfred Kienpointner (eds.), In simplicitate complexitas. Festgabe für Barbara Stefan zum 70. Geburtstag, 69-86. Wien: Praesens Verlag.

Bidese, Ermenegildo, Andrea Padovan \& Alessandra Tomaselli. 2012b. A binary system of complementizers in Cimbrian relative clauses. Working Papers in Scandinavian Syntax 90. 1-21. 
Online: http://project.sol.lu.se/uploads/media/Bidese_et_al_WPSS90_02.pdf (accessed 7 November 2016).

Bidese, Ermenegildo, Andrea Padovan \& Alessandra Tomaselli. 2013. Bilingual competence, complementizer selection and mood in Cimbrian. In Werner Abraham \& Elisabeth Leiss (eds.), Dialektologie in neuem Gewand. Zu Mikro-/Varietätenlinguistik, Sprachenvergleich und Universalgrammatik (Linguistische Berichte - Sonderhefte 19), 47-58. Hamburg: Buske Verlag.

Bidese, Ermenegildo, Andrea Padovan \& Alessandra Tomaselli. 2014. The syntax of subordination in Cimbrian and the rationale behind language contact. Language Typology and Universals - STUF Sprachtypologie Und Universalienforschung 67(4). 489-510.

Bidese, Ermenegildo \& Alessandra Tomaselli. 2007. Diachronic development in isolation: The loss of V2 phenomena in Cimbrian. Linguistische Berichte 210. 209-228.

Bidese, Ermenegildo \& Alessandra Tomaselli. 2016. The decline of asymmetric word order in Cimbrian subordination and the special case of umbrómm. In Ingo Reich \& Augustin Speyer (eds.), Co- and subordination in German and other languages (Linguistische Berichte Sonderhefte 21), 55-75. Hamburg: Helmut Buske Verlag.

Cinque, Guglielmo. 2010. The syntax of adjectives. A comparative study. Cambridge, Massachusetts: Massachusetts Institute of Technology Press.

Cinque, Guglielmo. 2014. The semantic classification of adjectives. A view from syntax. Studies in Chinese Linguistics 35. 3-32.

Cognola, Federica. 2013. Syntactic variation and verb second: A German dialect in Northern Italy (Linguistik Aktuell/Linguistics Today 201). Amsterdam \& Philadelphia: John Benjamins.

Dal Negro, Silvia. 2004. The decay of a language. The case of a German dialect in the Italian Alps. Bern: Peter Lang.

Dal Negro, Silvia. 2014. Language contact and variation patterns in Walser German subordination. Language Typology and Universals - STUF Sprachtypologie und Universalienforschung 67(4). 287-338.

Dorian, Nancy C. 2010. Investigating Variation. The effects of social organization and social setting. Oxford: Oxford University Press.

Dürscheid, Christa. 2002. Polemik satt und Wahlkampf pur. Das postnominale Adjektiv im Deutschen. Zeitschrift für Sprachwissenschaft 21(1). 57-81.

Gamillscheg, Ernst. 1912. Die romanischen Elemente in der deutschen Mundart von Lusern. Halle/Saale: Max Niemeyer.

Giusti, Giuliana. 2002. The functional structure of determiners. A bare phrase structure approach. In Guglielmo Cinque (ed.), The cartography of Syntactic Structure, vol. 1: Functional Structure in DP and IP, 54-90. Oxford: Oxford University Press.

[Linguistics 57(2), 393]

Grewendorf, Günther \& Cecilia Poletto. 2009. The hybrid complementizer system in Cimbrian. In Vincenzo Moscati \& Emilio Servidio (eds.), Proceedings XXXV Incontro di Grammatica Generativa, 181-194. Siena: Centro Interdipartimentale di Studi Cognitivi sul Linguaggio. http://www.ciscl.unisi.it/doc/doc_pub/STiL-2009-vol3-special-IGG.pdf (accessed 7 November 2016).

Grewendorf, Günther \& Cecilia Poletto. 2011. Hidden verb second: The case of Cimbrian. In Michael Putnam (ed.), Studies in German-Language Islands (Studies in Language Companion Series 123), 301-346. Amsterdam \& Philadelphia: John Benjamins.

Guardiano, Cristina. 2014. Fenomeni di contatto sintattico in Italia meridionale? Alcune note comparative. In Diego Pescarini \& Silvia Rossi (eds.), Quaderni di lavoro ASIt 18, 73-102. Padova: Università degli Studi di Padova.

Kolmer, Agnes. 2005. Subjektklitika als Kongruenzmarkierer: Ein Vergleich zwischen bairischen und alemannischen Sprachinseldialekten in Norditalien (Zimbrisch und Walserdeutsch). In Ermenegildo Bidese, James R. Dow \& Thomas Stolz (eds.), Das Zimbrische zwischen Germanisch und Romanisch (Diversitas Linguarum 9), 164-189. Bochum: Brockmeyer.

Kolmer, Agnes. 2012. Pronomina und Pronominalklitika im Cimbro. Untersuchungen zum grammatischen Wandel einer deutschen Minderheitensprache in romanischer Umgebung. Stuttgart: Steiner.

Kranzmayer, Eberhard. 1981-1985 [1923]. Laut- und Flexionslehre der deutschen zimbrischen Mundart: Das sind die Mundarten in den 7 vincentinischen Gemeinden, den 13 Veroneser Gemeinden und den deutschen Orten im Trentinischen (mit Ausnahme des Fersentales und des Nonsberges) 2 Voll. Edited by Maria Hornung. Wien: Verband der wissenschaftlichen Gesellschaften Österreichs. 
Laenzlinger, Christopher. 2005. Some notes on DP-internal movement. Generative Grammar in Geneva 4. 227-260.

Lindgren, Anna-Riitta. 1999. Linguistic variation and the historical sociology of multilingualism in Kven communities. In Ernst Håkon Jahr (ed.), Language Change. Advances in Historical Sociolinguistics, 141-166. Berlin \& New York: Mouton de Gruyter.

Mattiola Tiziano, M. 1985. Un caso di decadenza linguistica: Mòcheno, Trentino e Italiano in contatto nella Valle del Fèrsina. Zürich: University of Zürich dissertation.

Meid, Wolfgang. 1985. Der erste zimbrische Katechismus. Christliche unt korze dottrina. Die zimbrische Version aus dem Jahre 1602 der Dottrina christiana breve des Kardinals Bellarmin in kritischer Ausgabe. Einleitung, italienischer und zimbrischer Text, Übersetzung, Kommentar, Reproduktionen. Innsbruck: Institut für Sprachwissenschaft der Universität Innsbruck.

Padovan, Andrea. 2011. Diachronic clues to grammaticalization phenomena in the Cimbrian CP. In Michael Putnam (ed.), Studies in German-Language Islands (Studies in Language Companion Series 123), 279-299. Amsterdam \& Philadelphia: John Benjamins.

Padovan, Andrea \& Claudia Turolla. 2016. Il sintagma nominale nel Cimbro di Luserna: Osservazioni sulla modificazione aggettivale. In Patrizia Cordin \& Alessandro Parenti (eds.), Problemi e prospettive della linguistica storica. Atti del XL Convegno della Società Italiana di Glottologia, 201-212. Roma: Il Calamo.

Panagiotidis, E. Phoevos. 2008. Diachronic stability and feature interpretability. In Theresa Biberauer (ed.), The limits of syntactic variation (Linguistik Aktuell/Linguistics Today 132), 441-546. Amsterdam \& Philadelphia: John Benjamins.

Panieri, Luca, Monica Pedrazza, Adele Nicolussi Baiz, Sabine Hipp \& Cristina Pruner. 2006. Bar lirnen z'schraiba un zo reda az be biar. Grammatica del cimbro di Luserna/Grammatik der

[Linguistics 57(2), 394]

zimbrischen Sprache von Lusern. Trento \& Luserna: Regione Autonoma Trentino-Alto Adige/Autonome Region Trentino-Südtirol \& Istituto Cimbro/Kulturinstitut Lusérn.

Paul, Hermann. 2007. Mittelhochdeutsche Grammatik, 25th edn. Neubearbeitet von Thomas Klein, Hans-Joachim Solms \& Klaus-Peter Wegera. Mit einer Syntax von Ingeborg Schöbler, neubearbeitet und erweitert von Heinz-Peter Prell. Tübingen: Max Niemeyer Verlag.

Poletto, Cecilia. 2013. On the internal structure of q-words. In Werner Abraham \& Elisabeth Leiss (eds.), Dialektologie in neuem Gewand. Zu Mikro-/Varietätenlinguistik, Sprachenvergleich und Universalgrammatik (Linguistische Berichte - Sonderhefte 19), 85-101. Hamburg: Buske Verlag.

Poletto, Cecilia \& Alessandra Tomaselli. 2002. La sintassi del soggetto nullo nelle isole tedescofone del Veneto: Cimbro e Sappadino a confronto. In Gianna Marcato (ed.), La dialettologia oltre il 2001. Atti del convegno di Sappada/Plodn (Belluno), 1-5 luglio 2001, 237-252. Padova: Unipress.

Roehrs, Dorian. 2014. The inner makeup of definite determiners: The case of Germanic. Journal of Germanic Linguistics 25(04). 295-411.

Rowley, Anthony 2001. Deskriptive Grammatik des Deutsch-Fersentalerischen (Mòcheno), Augsburg. http://publikationen.ub.uni-frankfurt.de/files/14831/Deskriptive_Grammatik_Rowley.pdf (accessed 7 November 2016).

Schmeller, Johann Andreas 1838. Über die sogenannten Cimbern der VII und XIII Communen auf den Venedischen Alpen und ihre Sprache. Denkschriften der bayer. Akademie der Wissenschaften 15 - Abhandlungen der philos.-philol. Klasse 2, 555-708 [Reprint in: Schmeller, Johann Andreas. 1984. Die Cimbern der VII und XIII Communen und ihre Sprache. Edited by Richard J. Brunner, 13-162. Landshut: Curatorium Cimbricum Bavarense].

Schweizer, Bruno. 2008 [1951/1953]. Zimbrische Gesamtgrammatik. Vergleichende Darstellung der zimbrischen Dialekte. Edited by James R. Dow. Stuttgart: Steiner Verlag.

Trost, Igor. 2006. Die nicht-flektierten Adjektive. Zeitschrift für germanistische Linguistik 34. 374393.

Truswell, Robert. 2009. Attributive adjectives and nominal templates. Linguistic Inquiry 40. 525533.

Tyroller, Hans. 1994. Die Mundart von Lusern. In Maria Hornung (ed.), Studien zur Dialektologie III. Die Deutschen Sprachinseln in den Südalpen. Mundarten und Volkstum, 109-144. Hildesheim, Zürich, New York: Georg Olms Verlag.

Tyroller, Hans. 2003. Grammatische Beschreibung des Zimbrischen von Lusern [Zeitschrift für Dialektologie und Linguistik - Beihefte 111]. Stuttgart: Steiner.

Zampedri, Monica 1995. Mòcheno, Trentino e Italiano a contatto nella Valle del Fèrsina. Trento: University of Trento dissertation. 